\title{
MATHEMATICAL MODEL FOR BALANCING FEED RATIONS IN DAIRY COWS
}

\author{
Janzekovic, M.; RozMan, C.; PAZeK, K. \& Pevec, P.
}

Abstract: Due to milk and fodder price fluctuations the milk producers must constantly adapt in order to stay competitive. Since fodder costs can represent over $40 \%$ of total costs in dairy cows they can decisively impact the economic feasibility of the operation. The importance of balanced feeding rations and cost efficiency is thus a decisive parameter in economics of dairy cows. The aim of this paper is to present one of the manners how to prepare fodder meal for dairy cows with satisified requirements. We will practically show two examples of meals for dairy cows. One of the examples is entering raw material by hand and the second one with using a mathematical model for optimisation fodder meals for dairy cows. The model is developed in Whats Best 9 (WB!9) for Excel.

Key words: feed ration, optimisation, mathematical programming, dairy cows
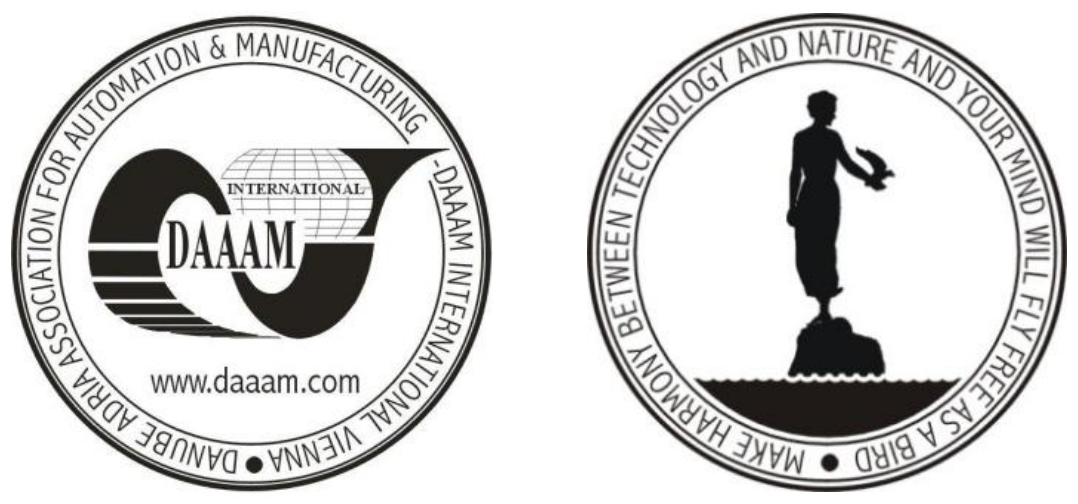

Authors' data: Assist. Prof. PhD. Janzekovic, M[arjan]; Full Prof. PhD. Rozman, C[rtomir]; Assoc. Prof. PhD. Pazek K[armen]; Pevec, P[rimoz], University of Maribor, Faculty of Agriculture and Life Sciences, Pivola 10, 2311, Hoce, Slovenia, marjan.janzekovic@um.si,crt.rozman@um.si,karmen.pazek@um.si, primoz.pevec@siol.net

This Publication has to be referred as: Janzekovic, M[arjan]; Rozman, C[rtomir]; Pazek, K[armen] \& Pevec, P[rimoz] (2014). Mathematical Model for Balancing Feed Rations in Dairy Cows, Chapter 12 in DAAAM International Scientific Book 2014, pp.153-162, B. Katalinic (Ed.), Published by DAAAM International, ISBN 978-3901509-98-8, ISSN 1726-9687, Vienna, Austria

DOI: $10.2507 /$ daaam.scibook.2014.12 
Janzekovic, M.; Rozman, C.; Pazek, K. \& Pevec, P.: Mathematical Model for Balan...

\section{Introduction}

Considerable research has been conducted over the years to determine optimal rations for different kind of cattle. The optimal ration should meet all basic nutrient requirements. Simultaneously, costs of the feeding ration should be minimized. Mathematical programming emerges as possible solution for milking cow feeding cost minimization problem (Rozman et al., 2002). Mathematical programming is a standard optimisation tool for solving diet problems in human or animal nutrition (Darmon et al., 2002). The goal is to find variable values thet produce maximum or minimum value of the objective function within the defined constraints (Zgajnar et al., 2007). Sometimes the goals in the diet problem might be conflicting and that results with no feasible solution or unbounded (Fergusson et al., 2006).

The modern information technology enables fast and efficient solving of mathematical programs with large number of variables and constraints. Since many modern optimisation tools operate in spreadsheet environment, the results of optimisation models can be directly linked to enterprise budgets in the form of decision support systems and that enables efficient and succsefull management of dairy cow operation. However, the model formulation requires expertise in mathematical programming as well as animal nutrition. Pevec (2012) developed a optimisation model for dairy cows diet problem using Excel 2007 in combination with optimisation software What's best Industrial 9.0 by Lindo Systems.

What'sBest! 9.0 makes available to Microsoft Excel spreadsheet program a highly developed solver capable of performing linear, integer, quadratic, and nonlinear optimization on the most difficult of problems. What'sBest! gives access to this solver from within Excel, and may either be run directly or called from within Visual Basic. The earliest version of What'sBest! became available in 1984 for VisiCalc, and What'sBest! has been under continuous development since then. Models have been built for What'sBest! that solve problems in virtually every field of professional endeavor. What'sBest! 9.0 include major solver enhancements to increase speed and reliability on broad classes of linear, integer, quadratic and general nonlinear models. Other significant enhancements include an improved global solver, an updated presolver and greater user control over the solution process (Archives - What'sBest! 9.0, 2014).

When solving nutrition problems we also have to deal with non linear constraints, for instance the ratio between minerals (Darmon et al., 2002). Likewise the objective function can be non linear (Zgajnar et al., 2007). We can find many examples of diet problem solving with optimisation (Prisenk et al., 2014). Since the milk production and number of dairy cows have been increasing recently, however, due to demanding market situation the costs savings in dairy cow management is essential and therefore the optimisation with feeding cost minimisation has become a standard management tool in dairy cow operation, moreover, the Excel based optimisation models can be easily connected to other management calculations (Rozman et al., 2006). Different forms of mathematical programming for animal feed optimisation, input use in 
agriculture, were also used by Stokes and Tozer (2002), Gomez-Limon et al. (2004), Fergusson et al. (2006), and Prisenk et al. (2013).

The main objective of this study is to present an optimisation model for dairy cows diet problem that has been developed for a case study farm. The paper is organised as follows: first we present the model methodology and then the practical application on a case study. Final remarks and main findings conclude this paper.

\section{Materials and methods}

\subsection{Model development}

The model has been developed since 1998 when the simple spreadsheet programme for manual calculation of feeding ration was developed. The model used starch units for energy and crude proteins. The first version of a model did not include cost minimisation.

In the next years the model was upgraded into mathematical programme. The feeding rations were calculated using mathematical programming optimization method with minimization of total feeding ration costs as objective function. The mathematical model can be described with following equation:

$$
\begin{gathered}
\min \mathrm{CU}^{*} \mathrm{X} \\
\mathrm{C}^{*} \mathrm{X}>\mathrm{N} \\
\mathrm{C}^{*} \mathrm{X}<=\mathrm{K}^{*} \mathrm{~N} \\
\mathrm{X}>=0
\end{gathered}
$$

Where:

$\mathrm{CU}$ - price matrix for individual components of feeding rations

$\mathrm{C}$ - matrix of contents for each ingredient in the individual feeding component

$\mathrm{X}$ - matrix of quantities of indiviual components of feeding ration

$\mathrm{N}$ - matrix of normatives for individual components in the feeding ration at desired milk quantity and quality

$\mathrm{K}$ - tolerance coefficient for the maximum allowed surplus of individual component in the feeding ration

Additional constraints and nonlinear relationships (such as Ca:P ratio) have been additionally used in order to find optimal feeding rations.

The model operates in Visual basic for Excel (simulation model) and What's best Industrial for Excel 9.0 (calculation of feeding ratios) optimization environment which is able to solve nonlinear mathematical programs. The control panel of What's best Industrial for Excel 9.0 can be seen on Figure 1. 
Janzekovic, M.; Rozman, C.; Pazek, K. \& Pevec, P.: Mathematical Model for Balan...

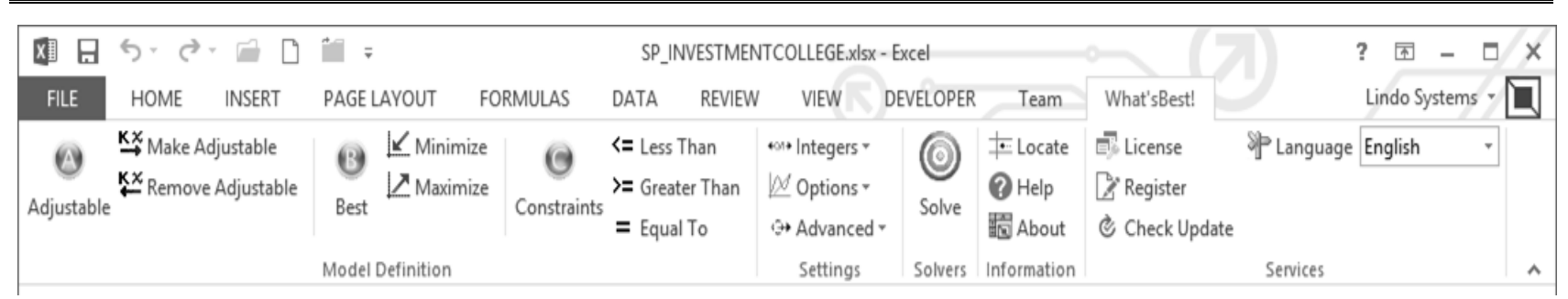

Fig. 1. Command panel of What's best Industrial for Excel 9.0

\section{Results with discussion}

The model is in fact a series of equations in spreadsheet 1) calculates nutrition requirements (feeding normatives) on the basis of input data and 2) the quantities of feeding components in the optimal solution.

The first input data include weight of the cow and information whether the animal is increasing or decreasing weight (Table 1). In the period after delivery the animal weight is decreasing while it is increasing in the $2^{\text {nd }}$ half of the milk production period (lactation). The weight loss/gain varies between $0.1-0.5 \mathrm{~kg}$ per day. The weight has increased over $700 \mathrm{~kg}$ as a result of breeding (Janzekovic et al., 2012). For the correct input data the animal should be weighted. On the basis of the weight the model calculated the requirments for weight maintainance as demonstrated in Table 3.

\begin{tabular}{|l|c|}
\hline Inputs & Entries \\
\hline Body weight $(\mathrm{kg})=$ & 730 \\
\hline Weight increase $(+)(\mathrm{kg})$ & 0.00 \\
\hline Weight decrerase $(-)(\mathrm{kg})$ & 0.20 \\
\hline
\end{tabular}

Tab. 1. The basic model input data

The next model inputs are expected milk production $(\mathrm{kg})$, protein and fat content (g). Using all these data the model calculates feeding normatives required for milk production (Table 2).

\begin{tabular}{|l|c|}
\hline Inputs & Entries \\
\hline Fat $(\mathrm{g})$ & 40 \\
\hline Protein $(\mathrm{g})$ & 35 \\
\hline Expected milk quantity $(\mathrm{kg})$ & 28 \\
\hline
\end{tabular}

Tab. 2. Input data for milk production per cow

Table 3 shows calculated feeding total normatives for weight maintainance and milk production. On the basis of the equations in Figure 1 (Babnik et al., 2002) the need for energy and nutrients for maintenance of chosenbody weight (Table 1) was calculated, which are shown in Table 3 in the column Maintenance. In the next step the expected needs for milk production for chosen milk production in $\mathrm{kg}$ and expected milk quality based on chosen fats (g) and proteins (g) per kilogram of milk were calculated. The calculated overall needs of the expected production are shown in Table 3 in column Milk production. Column Cumulativ in the same table shows 
the total requirements for nutrients representing a total need for nutrients and should be covered from the calculated meal.

\begin{tabular}{|c|c|c|c|}
\hline Nutrientes & Maintenance & Milk production & Cumulative \\
\hline NEL $(\mathrm{MJ})$ & 37.42 & 90.58 & 128.00 \\
\hline $\mathrm{DCP}(\mathrm{g})$ & 295.41 & 1369.06 & 1664.47 \\
\hline $\mathrm{DM}(\mathrm{kg})$ & 21.66 & & 21.66 \\
\hline $\mathrm{CF} \mathrm{max}(\mathrm{g})$ & 3898.80 & & 3898.80 \\
\hline $\mathrm{Ca}(\mathrm{g})$ & 30.00 & 89.6 & 119.60 \\
\hline $\mathrm{P}(\mathrm{g})$ & 20.00 & 47.6 & 67.60 \\
\hline $\mathrm{Mg}(\mathrm{g})$ & 12.00 & 25.2 & 37.20 \\
\hline $\mathrm{Na}(\mathrm{g})$ & 10.00 & 33.6 & 43.60 \\
\hline
\end{tabular}

Legend: NEL - neto energy for lactation, DCP - digestabel crude protein, $\mathrm{CF}$ - crude fiber, $\mathrm{DM}$ - dry matter, $\mathrm{MP}_{\mathrm{E}}$ - metabolised protein on energy, $\mathrm{MP}_{\mathrm{N}}-$ metabolised protein on nitrogen

Tab. 3. Cumulative normatives for weight maintainance and milk production

\begin{tabular}{|c|c|c|c|}
\hline Nutrients & Upper limit & Logical value & Lower limit \\
\hline $\mathrm{MP}_{\mathrm{E}}$ & 2492.58 & $=$ & 2492.58 \\
\hline $\mathrm{MP}_{\mathrm{N}}$ & 2492.58 & $=$ & 2492.58 \\
\hline $\mathrm{NEL}$ & 182.74 & $=$ & 182.74 \\
\hline $\mathrm{Ca}$ & 174.00 & $=$ & 174.00 \\
\hline $\mathrm{P}$ & 96.50 & $=$ & 96.50 \\
\hline $\mathrm{Mg}$ & 53.98714 & Not $=$ & 52.50 \\
\hline $\mathrm{Na}$ & 64.00 & $=$ & 64.00 \\
\hline Dry mater & 27.57692 & Not $=$ & 24.40 \\
\hline Grazing & 0.00 & $=$ & 0.00 \\
\hline $\mathrm{CF}$ & 5368.00 & $=$ & 5368.00 \\
\hline Proportion DM & 2.871328 & $<=$ & 12.2 \\
\hline Minerals & 0.35 & $<=$ & 0.53 \\
\hline Hay & 0.50 & $=$ & 0.50 \\
\hline Mais silage & 17.00 & $=$ & 17.00 \\
\hline Grass silage & 21.00 & $=$ & 21.00 \\
\hline
\end{tabular}

Tab. 4. Constrainsts of the optimisation model

The problem can arise when the model return illogical solutions, for instance large quantities of energy components (such as maize etc.). In this case additional connstraints are required: for instance the quantity energy and protein components must stay bellow $50 \%$ in the feeding ration. Likewise, the additional constraint for minimum share of the voluminous components in the feeding ration can be included as demonstrated in Table 4.

The spreadsheet model can be used for efficient and fast recalculation for any input changes (prices, component chemical analysis etc.). Since the feasible solution cannot always be found the additional constraints for tolerance $( \pm 10 \%)$ are also included. 
Janzekovic, M.; Rozman, C.; Pazek, K. \& Pevec, P.: Mathematical Model for Balan...

The calculated data on feeding ration can also be connected to other spreadsheet models (for instance enterprise budgets and whole farm plans) and can be used for whole farm planning in the form of decision support system.

\subsection{Case study}

In the next section we present real applications of the presented optimisation model. In case 1 we have no assumption on components quantities.

\subsubsection{Case 1: Optimisationwithout any constrains on basic feeding components}

On the basis of the presented input data the feeding requirements/normatives are calculated and presented in Table 5.

\begin{tabular}{|c|c|}
\hline & Total requirements \\
\hline Nutrient & Value \\
\hline NEL $(\mathrm{MJ})$ & 124.51 \\
\hline $\mathrm{DCP}(\mathrm{g})$ & 1612.47 \\
\hline $\mathrm{DM}(\mathrm{kg})$ & 20.10 \\
\hline $\mathrm{CF}(\mathrm{g})$ & 4321.50 \\
\hline $\mathrm{Ca}(\mathrm{g})$ & 116.40 \\
\hline $\mathrm{P}(\mathrm{g})$ & 65.90 \\
\hline $\mathrm{Mg}(\mathrm{g})$ & 36.30 \\
\hline $\mathrm{Na}(\mathrm{g})$ & 42.40 \\
\hline
\end{tabular}

Tab. 5. Total requirements (weight maintainnace and milk production)

The input data are s follows: animal weight $=730 \mathrm{~kg}$, expected milk production $=27 \mathrm{~kg}$, fat content $=40 \mathrm{~g} / \mathrm{kg}$, protein content $=35 \mathrm{~g} / \mathrm{kg}$, weight decrease $=0.15$ $\mathrm{kg} / \mathrm{day}$.

Table 6 shows the chemical composition of the feeding components. We run the model with objective function for minimum feeding ration costs. The chemical composition on farm produced feeding components is based on chemical analysis. We used producer's data on chemical composition for purchased high energy and protein components. The prices for on farm produced components are from enterprise budgets (production cost in $€ /$ unit) and retail prices for purchased components (€/unit).

In this case the model calculated following feeding ration (Table 7): $16.99 \mathrm{~kg}$ grass sillage, $25.1 \mathrm{~kg}$ maize sillage, $1.82 \mathrm{~kg}$ maize, $2.13 \mathrm{~kg}$ protein mixture (36\% of protein), $0.23 \mathrm{~kg}$ rumisal and $0.06 \mathrm{~kg}$ of soda.

In the last 2 rows we can see total quantities of individual components compared to the requirements (last row). We can see that all calculated quantities are within tolerance or equal to the requirememnts. In this case the model found a local optimall solution. The costs of this feeding ration are $2.68 € /$ day.

The contents of individual nutrients were within the limits of admissibility deviations, which is less than 5 units for each nutritional components in the row "total". 


\begin{tabular}{|l|c|c|c|c|c|c|c|c|}
\hline $\begin{array}{l}\text { Feeding } \\
\text { component }\end{array}$ & $\begin{array}{c}\text { Quantity } \\
(\mathrm{kg})\end{array}$ & $\mathrm{MP}_{\mathrm{E}}(\mathrm{g})$ & $\mathrm{MP}_{\mathrm{N}}(\mathrm{g})$ & $\begin{array}{c}\mathrm{NEL} \\
(\mathrm{MJ})\end{array}$ & $\begin{array}{c}\mathrm{Ca} \\
(\mathrm{g})\end{array}$ & $\begin{array}{c}\mathrm{P} \\
(\mathrm{g})\end{array}$ & $\begin{array}{c}\mathrm{Mg} \\
(\mathrm{g})\end{array}$ & $\begin{array}{c}\mathrm{Na} \\
(\mathrm{g})\end{array}$ \\
\hline Hay & 0.00 & 77 & 71 & 5 & 7 & 3.2 & 1.8 & 0.22 \\
\hline Grass silage & 16.99 & 60 & 80 & 5.5 & 4.8 & 3.8 & 1.4 & 0.65 \\
\hline Grazing & 0.00 & 80 & 95 & 5.7 & 1 & 0.65 & 0.35 & 0.2 \\
\hline Maize silage & 25.10 & 52 & 41 & 6.2 & 4.2 & 1.74 & 1.3 & 0.2 \\
\hline Maize & 1.82 & 112 & 83 & 8.5 & 0.3 & 2.8 & 0.9 & 0.23 \\
\hline $\begin{array}{l}\text { Rapeseed } \\
\text { cake }\end{array}$ & 0.00 & 125 & 203 & 7.5 & 8 & 1 & 2.3 & 2.18 \\
\hline $\begin{array}{l}\text { Sonflover } \\
\text { cake }\end{array}$ & 0.00 & 112 & 231 & 5.8 & 3.5 & 4 & 4 & 0.2 \\
\hline $\begin{array}{l}\text { Protein } \\
\text { mixture }\end{array}$ & 2.13 & 280 & 280 & 6.2 & 5 & 4 & 4 & 0.5 \\
\hline K-TOP 40 & 0.00 & 155 & 170 & 7.2 & 8 & 4.5 & 2.5 & 4 \\
\hline K-18 & 0.00 & 135 & 145 & 6.2 & 8 & 4.5 & 2.5 & 4 \\
\hline K-TOP 50 & 0.00 & 165 & 180 & 7.8 & 8 & 4.5 & 2.5 & 3.5 \\
\hline Glicolac & 0.00 & 60 & 65 & 8.8 & 7 & 1 & 1.6 & 1.2 \\
\hline Rumisal 5 & 0.00 & 0 & 0 & 0 & 220 & 40 & 25 & 90 \\
\hline $\begin{array}{l}\text { Rumisal dry } \\
\text { cow }\end{array}$ & 0.00 & 0 & 0 & 0 & 0 & 90 & 80 & 100 \\
\hline Rumisal 3 & 0.23 & 0 & 0 & 0 & 160 & 50 & 25 & 90 \\
\hline Soda 27\% & 0.06 & 0 & 0 & 0 & 0 & 0 & 0 & 270 \\
\hline Total & 46.34 & 1612.5 & 1607.4 & 121.6 & 117.2 & 65.9 & 36.3 & 42.4 \\
\hline Norm & & 1612.5 & 1612.5 & 124.5 & 116.4 & 65.9 & 36.3 & 42.4 \\
\hline
\end{tabular}

Tab. 6. Chemical composition of the feeding components used in the model

\begin{tabular}{|l|c|c|c|c|c|c|}
\hline $\begin{array}{l}\text { Feeding } \\
\text { component }\end{array}$ & $\begin{array}{c}\text { Quantity } \\
(\mathrm{kg})\end{array}$ & $\begin{array}{c}\mathrm{DM} \\
(\mathrm{kg})\end{array}$ & $\begin{array}{c}\mathrm{CF} \\
(\mathrm{g})\end{array}$ & $\begin{array}{c}\text { Price / kg } \\
(€)\end{array}$ & $\begin{array}{c}\text { Total price DM } \\
(€)\end{array}$ & $\begin{array}{c}\text { Total price } \\
(€)\end{array}$ \\
\hline Grass silage & 16.99 & 7.14 & 1890.9 & 0.05 & 0.36 & 0.85 \\
\hline Grazing & 0.00 & 0.00 & 0.0 & 0.011 & 0.00 & 0.00 \\
\hline Maize silage & 25.10 & 9.21 & 2165.2 & 0.034 & 0.31 & 0.85 \\
\hline Maize & 1.82 & 1.60 & 40.0 & 0.15 & 0.24 & 0.27 \\
\hline Rapeseed cake & 0.00 & 0.00 & 0.0 & 0.175 & 0.00 & 0.00 \\
\hline Sonflover cake & 0.00 & 0.00 & 0.0 & 0.175 & 0.00 & 0.00 \\
\hline Protein mixture & 2.13 & 1.88 & 225.4 & 0.24 & 0.45 & 0.51 \\
\hline Rumisal 3 & 0.23 & 0.22 & 0.0 & 0.68 & 0.15 & 0.16 \\
\hline Soda 27\% & 0.06 & 0.06 & 0.0 & 0.5 & 0.03 & 0.03 \\
\hline Total & 46.34 & 20.1 & 4321.5 & & & 2.68 \\
\hline
\end{tabular}

Tab. 7. Calculation total costs of the feeding ration

Table 7 also demonstrates contents of dry matter and crude fiber in individual components for the calculated feeding ration. 
Janzekovic, M.; Rozman, C.; Pazek, K. \& Pevec, P.: Mathematical Model for Balan...

\subsubsection{Case 2: Limited quantities of basic feeding}

Since the yelds of basic feeding components are subject to production risk their availability may be limited. Therefore, in case 2 we constrain the availability of maize sillage and grass sillage with additional constraints as demonstrated on Table 8. In practise this way is used when we know the annual yields of basic feed components. In the model this is done in a way that constrasints (available daily quantities) are out in on the left side of the inequalities in the input tables.

\begin{tabular}{|c|c|c|c|}
\hline Hay & 2.0 & $<=$ & 2.0 \\
\hline Maizesillage & 18.0 & $=<=$ & 18.0 \\
\hline Grass sillage & 18.0 & $=<=$ & 18.0 \\
\hline
\end{tabular}

Tab. 8. Additional constraints (voluminous) of basic feeding components

In this case the feeding ration is as follows:

$18 \mathrm{~kg}$ of maize sillage, $18 \mathrm{~kg}$ of grass sillage, $2.59 \mathrm{~kg}$ of maize, $2 \mathrm{~kg}$ of protein mixture, $160 \mathrm{~g}$ of rumisal, $170 \mathrm{~g}$ of glicolac, $80 \mathrm{~g}$ of soda.

The costs in this case are $2.94 € /$ day. We can observe the cost increase compared to case 1 (no limitations for feeding components).

\subsection{Interpretation of results and advantaes/disadvantages}

The model has been tested on a real dairy farm since 2010. The results were also used as the basis for crop rotation planning. We run the model with no constraints on basic (volominouse) feeding components. The direct results were change in the ratio between grass and maize sillage and consequently changes in the farm crop rotation. Usually, the costs of the ration are higher with additional constraints. Possible changes on feeding components markets should also be considered. This use of models can help to improve understanding of agricultural systems, particularly those involving the dynamic interaction of many biological processes. In some there is a need for fur-ther research to establish the relationships between the system components. The improved understanding gained through model building can be valuable in directing research to provide the basic data required. Developing models as research tools may therefore be the first step toward producing practical aids for farm decision making. The proposed model should be applied as an appropriate analytical tool in order to assist the decision maker-farm operator (Glen, 1987; Rozman et al., 2006).

\subsubsection{Advantages}

The most reliable part of the model is calculation of feeding normatives (requirements). New standard units such as NEL (netoenery of lactation) and DCP (digestable crude proteins) are used in the model calculations. The input tables (prices, feeding components, chemical analysis) can easily be changed for each iteration of the model. This way the model can be adapted to any specific situation and it adequately reflects the reality. 


\subsubsection{Disadvantages}

The main disadvantage is that sometimes there is no feasible solution of the optimisation problem which usually occurs with very low or very high values of expected milk production. The problem of feasible solution also occurs on situation when many additional constraints are used.

\subsubsection{Further development}

The model should be upgraded for all cattle categories. Likewise, the model can be interconnected to other farm planning spreadsheet based models (for instance (optimisation of fertilizing plans, crop rotations and entrprise budgets). Other optimisation methods such as goal programming should also be considered. With little skill, our model can be successfully upgraded and linked to programs for herd management such as Westfalia Surge.

The proposed model should be applied as an appropriate analytical tool in order to assist the decision maker (farm operator). Likewise, the production parameters of individual cows should be regulary checked whether they rerflect model expectations. The real value of this study is the simulation model that enables evaluation of different scenarios on every single farm and can be, as such, used as decision support system on milk farms. Additional research to ensure more quality data for model input parameters and further upgrade of the model for other cattle categories sucs as steers/bulls, young cattle, or species are suggested.

\section{Conclusions}

We developed the model for optimisation of dairy cows feeding ration for the use on the farms and education. It contains all major ingredients and elements for modern dairy cow breeding. The feeding components prices are also included. Feeding requirements used in the model are based on the most recent findings in the literature and recent experience in dairy cows. The model minimizes the feeding ration costs.

The use of the model can contribute to improvement in dairy cows economics especially in periods of low prices. However, the importance of input data should also be stressed out here. Likewise, the optimal breeding technology should be used in order to fully exploit genetic potential of the herd.

Dairy cow breeding requires detailed management of the herd, elimination of the irregulatrities, ensure animal well fare and optimisation of feeding ration. The optimised ration should also be used in crop rotation planning. Despite limitations such as infeasible solutions in some cases the model fullfiled most of our expectations. The possibilities of the interrelation of optimisation model with Excel calculations such as enterprise budgets, whole farm plans present the main advantage of the presented approach. The approach is proposed as being both appropriate and advantageous when compared with other means of calculating feeding rations. 
Janzekovic, M.; Rozman, C.; Pazek, K. \& Pevec, P.: Mathematical Model for Balan...

\section{References}

Darmon, N., Ferguson, E. \& Briend, A. (2002). Linear and nonlinear programing to optimize the nutrient density of a populations diet. American Journal of clinical Nutrition, 75: 245-255. ISSN 0002-9165

Ferguson, E., Darmon, N., Fahmida, U., Fitriyanti, S., Harper, T.B. \& Premachandra, I.M. (2006). Design of optimal food-based complementary feeding recommendations and identification of key "Problem Nutrients" using goal programming. The Journal of Nutrition, 136 (9): 2399-2404. ISSN 0022-3166

Glen, J. J. (1987). Mathematical models in farm planning: a survey. Operations Research, 35(5): 641-666. ISSN 1526-5463

Gómez-Limón, J. A., Riesgo, L., \& Arriaza, M. (2004). Multi-Criteria Analysis of Input Use in Agriculture. Journal of Agricultural Economics, 55(3): 541-564. ISSN 1477-9552

Janzekovic, M., Janzekovic, I., Brus, M. \& Mursec, B. (2012). Quality of raw milk in different series of milk deliveries at milk-dispensers. V: Katalinic, Branko (Ed.). DAAAM International scientific book 2012, (DAAAM International scientific book, ISSN 1726-9687). Vienna: DAAAM International Publishing, 2012, 379-388

Prisenk, J., Pazek, K., Rozman, C., Turk, J., Janzekovic, M., \& Borec, A. (2013). Application of weighted goal programming in the optimization of rations for sport horses. Journal of Animal and Feed Sciences, 22(4): 335-341. ISSN 1230-1388.

Prisenk, J., Turk, J. \& Pazek, K. (2014). Optimization process in agriculture: Optimization processes on agricultural holdings with multi-objective programming approaches. Saarbrücken: Lap Lambert Academic Publishing, cop. 2014, 61 p. ISBN 978-3-659-55318-9

Rozman, C., Tojnko, S., Turk, J., Par, V. \& Pavlovic, M. (2002). Die Anwendung eines Computer simulations models zur Optimierung der Erweiterung einer Apfelplantage unter den Bedinungen der Republik Slowenien. Berichte über Landwirtschaft (The application of computer simulations models to optimize the extension of an apple orchard with regards conditions of the Republic of Slovenia. Reports on Agriculture ) 80 (4): 632-642. ISSN 0005-9080

Rozman, C., Pazek, K. \& Janzekovic, M. (2006). Feasibility analysis of three different catch crops for milking cow animal feed. Krmiva, 48(4), 163-173. ISSN 0023-4850.

Stokes, J. R., \& Tozer, P. R. (2002). Cost minimization and managing soil nutrient loading: Conflict or compromise?. Canadian Journal of Agricultural Economics/Revue canadienne d'agroeconomie, 50(2): 151-169. ISSN 1744-7976

Zgajnar, J., Kermauner, A. \& Kavcic, S. (2007). Estimation of ruminants' nutritional requirements and livestock ration optimisation. Society of Agricultural Economists Slovenia, Ljubljana, 279-288 